\title{
PENGARUH ANGKA MELEK HURUF DAN INFLASI TERHADAP PENGANGGURAN DI PROVINSI JAWA TENGAH
}

\author{
Dyah Ayu Arianti \\ Pendidikan Ekonomi, Jurusan Pendidikan Ekonomi, Fakultas Ekonomi, Universitas Negeri Surabaya, \\ e-mail: arianti57@gmail.com
}

\begin{abstract}
Abstrak
Penelitian ini bertujuan untuk menganalisis dampak tingkat melek huruf serta inflasi parsial dan simultan terhadap pengangguran pada provinsi Jawa Tengah. Data penelitian ini asal Badan pusat Statistik Provinsi Jawa Tengah data pendidikan, inflasi, serta pengangguran di provinsi Jawa Tengah pada tahun 2008-2018. Teknik analisis dalam penelitian ini artinya analisis regresi linier berganda menggunakan SPSS 16. hasil penelitian membagikan bahwa tingkat melek huruf secara parsial tidak memiliki dampak yg signifikan terhadap pengangguran pada provinsi Jawa Tengah di tahun 2008-2018, dan bahwa inflasi secara parsial memiliki imbas signifikan terhadap pengangguran di provinsi tadi. Jawa Tengah di 2008-2018. dengan demikian, nomor melek huruf serta inflasi tidak mempunyai imbas simultan pada pengangguran di provinsi Jawa Tengah selama periode 2008-2018.
\end{abstract}

\begin{abstract}
This observe tries to analyse the impact partial and simultaneous literation and inflation againt unemployment at primary java. Samples on this research is the extent of schooling, information reseach the extent of inflation and unemployment who Taken from the BPS primary java duration 2008-2018. evaluation techniques used on this studies is more than one linear regression evaluation using spss 16. The result confirmed that on partial literation does not have tremendous impact on unemployment in the province of important java period 2008-2018, on this fact inflation has have an effect on substantially to unemployment in the province of crucial java length 2008-2018. Then simultaneously literation and inflation isn't having an effect that changed into simultaneously towards unemployment in the province of imperative java period 2008-2018.
\end{abstract}

Keywords : literation, inflation, unemployment

\section{PENDAHULUAN}

Indonesia ialah negara berkembang yang awalnya hanya mengandalkan perekonomian pada sektor agraris serta ketika ini berkembang pada sektor industri. Total populasi Indonesia yaitu 265 juta orang. Populasi adalah 133,17 juta pria dan 131,88 juta wanita. Seringkali, masalah populasi termasuk masalah sosial ekonomi. Provinsi Jawa Tengah merupakan penyumbang pengangguran terbesar, mencapai 1,2 juta pada 2011 dan meningkat 1,6 juta pada Agustus 2012 (BPS, 2018).

Masalah ekonomi disebabkan oleh beberapa faktor yang berkaitan antara Pengangguran dan kemiskinan, kemudian pertumbuhan ekonomi (Sukirno, 2011), tingkat pendidikan (Suprayitno, 2015), angkatan kerja, dan upah (Pujoalwanto, 2014) yang bisa menjadikan jelek terhadap perekonomian, politik, dan sosial.

Masalah pemerintah provinsi Jawa Tengah adalah tingginya tingkat pengangguran yang menempati urutan kedua setelah provinsi Jawa Barat (BPS, 2018).

Namun ada kecenderungan turun, dapat dilihat pada tahun 2008 semester pertama yaitu bulan
Februari sebesar 7,12\% sedangkan pada tahun 2018 semester kedua yaitu pada bulan Agustus sebesar $4,51 \%$ terjadi penurunan $0,89 \%$. Secara terperinci dari aspek Pendidikan.

Satu aspek yang dapat mempengaruhi pengangguran yaitu pendidikan. (Suprayitno, 2015) mengungkapkan pendidikan pekerja berpengaruh terhadap pengangguran. pada Provinsi Jawa Tengah lebih banyak didominasi masih bermata pencaharian menjadi petani $47 \%$ nya adalah angkatan kerja. Sebagian akbar mata pencaharian ditemukan di sektor pertanian $(42,34 \%)$, perdagangan $(20,91 \%)$, industri $(15,71 \%)$ dan jasa $(10,98 \%)$.

Angka melek alfabet pada Jawa Tengah di tahun 2008-2018 terus meningkat yaitu pada tahun 2014 angka Melek huruf sebanyak $90,18 \%$ dan pada tahun 2018 sudah menjadi sebesar 94,5\%.

Menurut data dari BPS Jawa Tengah, selama periode 2008-2018 dapat dijelaskan terjadi fluktuatif dari tahun 2008 sampai 2018, namun dari tahun 2015 hingga 2018 nilai inflasi terbilang stabil di kisaran angka 2,5\%. Inflasi terjadi karena tingginya suatu permintaan kebutuhan pokok dan tempat tinggal. 
Angka Melek alfabet dengan memakai teori dari Von Thunen (1961) bahwa pendidikan yang tinggi membangun lapangan kerja sebagai akibatnya menghasilkan pendapatan yang besar . dari BPS (2018) Indikator yang dapat mengukur kesejahteraan sosial yaitu menggunakan cara melihat rendah dan tingginya persentase jumlah penduduk yang melek huruf. Dijadikan untuk mengukura didalam kemajuan suatu daerah. menggunakan ini kemampuan menulis serta membaca yang bisa dimiliki seorang dapat mendorong penduduk buat bisa berperan lebih aktif didalam proses pembangunan.

berdasarkan Friedman (1968) Inflasi adalah kenyataan moneter yang mengindikasikan terlalu banyaknya permintaan barang saat terlalu poly uang yg beredar. Inflasi yang dimaksudkan dalam penelitian ini ialah Indeks Harga Konsumen menggunakan memakai teori asal Friedman (1968) bahwa inflasi merupakan fenomena moneter yg mengindikasikan terlalu banyaknya permintaan barang waktu terlalu poly uang yang beredar

Sesuai perumusan persoalan pada atas, maka tujuan penelitian ini merupakan: (1) buat menganalisis imbas pendidikan yg diukur menggunakan indikator nomor Melek alfabet terhadap penganguran pada Provinsi Jawa Tengah.(2) buat menganalisis dampak inflasi yg diukur menggunakan indikator Indeks Harga Konsumen terhadap pengangguran pada Provinsi Jawa Tengah. (tiga) buat menganalisis imbas pendidikan yg diukur menggunakan indikator nomor Melek huruf serta inflasi yg dikur menggunakan indikator Indeks Harga Konsumen terhadap penganguran di Provinsi Jawa Tengah

\section{METODE}

Jenis penelitian ini merupakan penelitian kuantitatif. Populasi dalam penelitian ini adalah semua data tingkat pendidikan, tingkat inflasi dan pengangguran provinsi Jawa Tengah. Sedangkan sampel penelitian ini merupakan semua anggota populasi yaitu data tingkat pendidikan indikator diukur dengan nomor melek huruf, taraf inflasi diukur dengan indikator Indeks Harga Konsumen serta pengangguran provinsi Jawa Tengah di tahun 20082018 yg diambil berasal Badan pusat Statistik Jawa Tengah.

Metode yg akan digunakan peneliti adalah analisa Regresi Linier Berganda, meliputi uji Hipotesis (uji t, uji F dan koefisien determinasi)

\section{Hasil dan Pembahasan \\ 1. Pengaruh Angka Melek Huruf terhadap Pengangguran}

sesuai akibat pengujian hipotesis uji t didapat yang akan terjadi Variabel Pendidikan yang diukur dengan indikator nomor Melek alfabet tidak imbas pada pengangguran terbuka di tahun 2008-2018.

yang akan terjadi penelitian ini didukung sang penelitian yg dilakukan sang Suhendra dan Wicaksono (2016) yg menyimpulkan bahwa selama tahun 2010 hingga 2012, taraf pendidikan SMA (TPSMA) tidak memiliki efek yang signifikan.

Provinsi Jawa Tengah lebih banyak didominasi masih bermata pencaharian menjadi petani $47 \%$ di antaranya adalah angkatan kerja. Mata pencaharian paling banyak ialah pada bidang tani (42,34\%), diikuti menggunakan dagang $(20,91 \%)$, bidang industri $(15,71 \%)$, dan bidang jasa $(10,98 \%)$. Hal ini mengindikasikan bahwa penduduk Provinsi Jawa Tengah mata pencaharian di bidang ini diminati hampir setengah asal angkatan kerja terserap sehinga tidak membutuhkan pendidikan yang tinggi

Lapangan pekerjaan merupakan indikator penting taraf kesejahteraan masyarakat serta sekaligus sebagai indikator keberhasilan penyelenggaraan "pendidikan". Jika proses bepergian pendidikan sepanjang masa dipandang secara menyeluruh, maka bisa dilihat kenyataan bahwa kemajuan dalam pendidikan beriringan menggunakan kemajuan ekonomi secara bersamaan.

Pendidikan memiliki peran penting dalam membentuk kemampuan sebuah negara berkembang buat menyerap teknologi modern serta menyebarkan kapasitas supaya tercipta pertumbuhan dan pembangunan yg berkelanjutan (Todaro: 2006). Satu asal beberapa ciri pendidikan adalah kemampuan baca tulis yang ditunjukkan menggunakan indikator nomor Melek alfabet

angka melek alfabet bisa untuk jadi indikator melihat perkembangan pendidikan di masyarakat. semakin tinggi angka melek alfabet atau kecakapan baca tulis, maka meningkat juga kuantitas serta kualitas sdm. Penduduk yang bisa baca tulis disebut mempunyai kemampuan dan keterampilan karena bisa menyerap info baik itu verbal maupun tulisan (BPS, 2011:88)

tetapi pada penelitian ini, Indikator angka melek alfabet tidak mempunyai dampak terhadap pengangguran terbuka, dikarenakan ketika ini di waktu ini bursa kerja atau perusahaan pada 
merekrut karyawan baru lebih menentukan calon karyawan yang memiliki kompetensi yg tinggi tidak hanya sekedar mampu membaca atau melek alfabet sebagai akibatnya tidak berpengaruh terhadap nomor pengangguran terbuka pada Provinsi Jawa Tengah, hal ini antagonis menggunakan teori yang dikemukakan sang Von Thunen (1961) yg menyatakan Pendidikan yang tinggi membangun lapangan kerja sebagai akibatnya menghasilkan pendapatan yg besar.

\section{Pengaruh Inflasi terhadap Pengangguran}

sesuai hasil pengujian hipotesis uji t didapat yang akan terjadi bahwa Variabel Inflasi yg diukur menggunakan indikator Indeks harga konsumen memiliki nilai signifikan sebanyak 0,038 dibawah $0,05 \mathrm{yg}$ berarti terdapat imbas negatif secara parsial Inflasi terhadap pengangguran terbuka pada Provinsi Jawa Tengah tahun 2008-2018, lebih terang Koefisien regresi variabel inflasi sebanyak 0,083. Koefisien bernilai negatif adalah terjadi korelasi antagonis antara inflasi dengan pengangguran. semakin tinggi inflasi yg suatu daerah maka akan semakin turun pengangguran

Penelitian ini sejalan menggunakan penelitian Susanto dkk. (2017) menunjukan bahwa inflasi berpengaruh langsung terhadap Pengangguran pada Kota Samarinda, lalu pada penelitian Purnama (2015) dalam penelitiannya menyimpulkan bahwa inflasi berpengaruh negatif terhadap pengangguran

korelasi antara taraf inflasi dengan penganguran dasarnya di asumsi bahwa inflasi ialah cermin asal kenaikan permintaan agregrat. pada rangka memenuhi tingginya permintaan tadi, Produsen akan meningkatkan produktivitasnya buat pemenuhan kebutuhan rakyat, hal ini berimbas dengan penyerapan energi kerja. Hubungan taraf inflasi menggunakan penganguran ini berdasarkan di pendekatan harga asa (rational expectation), dimana pada saat itu dipergunakan variabel upah lalu diganti menggunakan variabel taraf harga serta kemudian tingkat harga diganti dengan taraf inflasi. Makin rendah penganguran, makin tinggi inflasi. kebalikannya apabila ada duduk perkara penganguran yg serius, taraf harga adalah relatif stabil. Berarti tidak praktis buat membentuk penggunaan energi kerja penuh dan kestabilan harga secara serentak (Sukirno:2000).

dampak yg lebih jauh adalah pengangguran sebagai meningkat. menggunakan demikian, tingkat inflasi dan taraf penganguran adalah dua parameter yg bisa dipergunakan untuk diukur baik buruknya kesehatan ekonomi pada suatu negara.

Inflasi berpengaruh negatif terhadap pengangguran terbuka dikarenakan inflasi yg terjadi karna tingginya permintaan gerombolan bahan kuliner, kuliner jadi, perumahan sebagai akibatnya dalam rangka memenuhi permintaan tadi pembuat membutuhkan poly energi kerja. oleh sebab itu penganguran akan jadi berkurang hal ini sama dengan teori yang dikatakan oleh Friedman (1968) yang menyatakan kenyataan moneter yg mengindikasikan terlalu banyaknya permintaan barang waktu terlalu banyak uang yg beredar

\section{Hubungan Angka Melek Huruf dan Inflasi dengan Pengangguran}

berasal akibat uji hipotesis uji $\mathrm{F}$, hasil penelitian menunjukkan bahwa angka $\mathrm{F}$ sebanyak 2,944 menggunakan taraf signifikan 0,072 di atas 0,05 , ini berarti pendidikan serta inflasi tidak berpengaruh secara simultan. pada variabel dependen. 48,2\% asal variabel dependen yaitu pengangguran bisa dijelaskan oleh dua variabel independen yang terdiri asal pendidikan serta inflasi, sedangkan sisanya 51,8\% dijelaskan oleh faktor lain pada luar contoh atau pada luar variabel pencarian.

angka melek huruf dan indeks harga konsumen tidak berpengaruh terhadap pengangguran sebab pada Provinsi Jawa Tengah lebih banyak didominasi masih bermata pencaharian menjadi petani $47 \%$ pada antaranya adalah angkatan kerja. Mata pencaharian paling banyak ialah pada bidang pertanian $(42,34 \%)$, diikuti bidang perdagangan $(20,91 \%)$, bidang industri $(15,71 \%)$, dan jasa (10,98\%). Hal ini menandakan bahwa penduduk Provinsi Jawa Tengah mata pencaharian pada bidang ini digeluti hampir separuh dari angkatan kerja terserap sehingga tidak membutuhkan pendidikan yg tinggi akibat penelitian ini bertentangan dengan (Suhendra, Indra, 2016) yang secara bersamaan menyimpulkan bahwa variabel independen memiliki dampak signifikan terhadap variabel dependen.

\section{PENUTUP}

\section{Kesimpulan}


sesuai analisa serta pembahasan maka bisa diambil kesirnpulan menjadi berikut: (1) tingkat melek alfabet tidak memiliki impak di provinsi Jawa Tengah di 2008-2018, yg bertentangan menggunakan teori (Von Thunen, 1961) bahwa tingkat melek huruf yang tinggi menciptakan lapangan kerja bagi membuat pendapatan yang signifikan (dua) Inflasi yang diukur dengan indikator indeks harga konsumen mempunyai efek negatif pada 2008-2018, sejalan dengan teori (Friedman, 1968) bahwa dia membuat fenomena moneter yang membagikan terlalu poly permintaan barang waktu terlalu banyak uang tersebar (3) Pendidikan serta inflasi tak memiliki impak simultan yg signifikan terhadap penganguran pada provinsi Jawa Tengah selama periode 2008-2018

\section{Saran}

Sesuai konklusi pada atas, saran / rekomendasi berikut dapat disajikan: (1) inflasi harus dilakukan buat menjaga daya beli masyarakat buat memenuhi kebutuhan mereka pada peningkatan kualitas hayati mereka (2) Bahwa Pemerintah Provinsi Jawa Tengah menciptakan pertumbuhan ekonomi dengan membuka pekerjaan buat mengurangi kemiskinan, sebagai akibatnya pertumbuhan ekonomi tercapai serta duduk perkara pengangguran berkurang. (3) Bagi para peneliti mereka perlu mengganti variabel pendidikan sebab tidak memiliki impak pada taraf pengangguran dan menaikkan jumlah tahun penelitian buat rnendapatkan hasil yg lebih akurat.

\section{Daftar pustaka}

BPS Provinsi Jawa Tengah. 2018. Statistik Statiktik Provinsi Jawa Tengah: BPS

Pujoalwanto, Basuki. 2014. Perekonomian Indonesia; Tinjauan Historis, Teoritis, dan Empiris. Yogyakarta: Graha Ilmu.

Purnama, Ika Purnama. 2015 Analisis Pengaruh Inflasi terhadap Tingkat Pengangguran Di Kota Medan Tahun 2000-2014. Jurnal Ekonomi Universitas Muhammadiyah Sumatera Utara

Suhendra, Indra, Bayu Hadi Wicaksono. 2016. Tingkat Pendidikan, Upah, Inflasi, dan Pertumbuhan Ekonomi terhadap Pengangguran Di Indonesia. Jurnal Ilmu Ekonomi Pembangunan, Universitas Sultan Ageng Tirtayasa

Sukirno, Sadono. 2011. Makro Ekonomi Teori Pengantar Edisi Ketiga. Rajawali Pers, Jakarta
Suprayitno, Iswahyudi dkk. 2015. "Pengaruh Tingkat Pendidikan terhadap Jumlah Pengangguran di Kota Semarang." Semarang: Universitas Negeri Semarang.

Susanto, Edyson, Eny Rochaida, Yana Ulfah. 2017. Pengaruh inflasi dan pendidikan terhadap pengangguran dan kemiskinan. Jurnal Ekonomi dan Bisnis Universitas Mulawarman, Samarinda.

Von Thunen, Johann H. 1961. Von Thunen's Isolated State. Peter Hall ed. London: Pergamon Press 